\title{
Acute fasciolosis in cattle in southern Brazil ${ }^{1}$
}

\author{
Maria de Lourdes Adrien ${ }^{2}$, Ana Lucia Schild ${ }^{3 *}$, Clairton Marcolongo-Pereira ${ }^{2}$, \\ Letícia Fiss ${ }^{2}$, Jerônimo L. Ruas ${ }^{3}$, Fabiane B. Grecco ${ }^{4}$ and Margarida B. Raffi ${ }^{4}$
}

\begin{abstract}
Adrien M.L., Schild A.L., Marcolongo-Pereira C., Fiss.L., Ruas J.L., Grecco F.B. \& Raffi M.B. 2013. Acute fasciolosis in cattle in southern Brazil. Pesquisa Veterinária Brasileira 33(6):705-709. Laboratório Regional de Diagnóstico, Faculdade de Veterinária, Universidade Federal de Pelotas, Campus Universitário s/n, Pelotas, RS 96010-900, Brazil. E-mail: alschild@terra.com.br

This study describes the epidemiological and pathological aspects of an outbreak of acute fasciolosis in cattle in southern Brazil. Fifteen out of 70 three-year-old pregnant cows lost weight in the 30-40 days prior to calving. Clinical signs included diarrhea, weakness, mild anemia and jaundice. Dark yellow fluid in the abdominal cavity was observed at necropsy. Fibrin and clotted blood were adhered to the pericardium and lung, primarily in the diaphragmatic lobes. The liver was enlarged, and the capsular surface was irregular with clear areas and petechiae. At the cut surface, the liver was irregular, firm and edematous, and several hemorrhagic channels could be observed. Areas of fibrosis through the parenchyma and whitish thrombi occluding the great vessels were also observed. The livers of 10 cows that not died were condemned at slaughter for lesions of fasciolosis similar to those observed at necropsy. Microscopically, the liver showed areas of coagulation necrosis, extensive hemorrhages in the streaks or foci and disruption of the parenchyma with neutrophil and eosinophil infiltration. Fibrosis and bile duct proliferation were also observed. Immature Fasciola hepatica flukes were observed in the parenchyma surrounded by degenerated hepatocytes, neutrophils, eosinophils, and hemorrhages. The outbreak occurred on a farm located in an area endemic for fasciolosis, although the acute form of the disease is not common in cattle in this region. It is likely that the cows were infected by F. hepatica metacercariae released in the late fall or early spring in the rice stubble where the herd was grazing prior to calving. Although mortality due to fasciolosis in cattle is infrequent, outbreaks can occur and treatments that are effective in both the immature and adult forms of the parasite should be administered to prevent economic losses.
\end{abstract}

INDEX TERMS: Fasciolosis, Fasciola hepatica, acute fasciolosis, fluke, cattle.

RESUMO.- [Fasciolose aguda em bovinos no Sul do Brasil.] Descrevem-se os aspectos epidemiológicos e patológicos de um surto de fasciolose aguda diagnosticado em bovinos na região sul do Rio Grande do Sul. De um lote de 70 vacas de três anos de idade 15 apresentaram perda de peso 30-40 dias antes da parição. Dessas, 10 vacas aborta-

\footnotetext{
${ }^{1}$ Received on November 24, 2012.

Accepted for publication on March 28, 2013.

2 Pós-Graduandos em Medicina Veterinária, Faculdade de Veterinária (FV), Universidade Federal de Pelotas (UFPel), Campus Universitário s/n, Pelotas, RS 96010-900, Brazil.

${ }^{3}$ Laboratório Regional de Diagnóstico, FV-UFPel, Campus Universitário s/n, Pelotas, RS. *Autor para correspondência: alschild@terra.com.br

${ }^{4}$ Departamento de Patologia Animal, Campus Universitário s/n, FV-UFPel, Pelotas, RS.
}

ram e 5 morreram. Os sinais clínicos caracterizaram-se por diarreia, fraqueza, anemia discreta e icterícia. Na necropsia havia líquido escuro na cavidade abdominal. Na cavidade torácica havia fibrina e coágulos de sangue aderidos ao pericárdio e pulmões, principalmente nos lobos diafragmáticos. O fígado estava aumentado de tamanho e a superfície capsular estava irregular com áreas claras e petéquias. A superfície de corte estava irregular, firme e edematosa e podiam ser observadas estrias hemorrágicas através do parênquima. Áreas de fibrose e trombos esbranquiçados ocluindo vasos sanguíneos foram, também, observados. Os fígados das 10 vacas que não morreram foram condenados no abate por lesões de fasciolose similares às observadas na necropsia. Microscopicamente, o fígado apresentava áreas de necrose de coagulação, focos de hemorragia acen- 
tuada e desorganização do parênquima com acentuada infiltração de neutrófilos e eosinófilos. Havia, ainda, fibrose e hiperplasia de células de ductos biliares. Formas imaturas de Fasciola hepatica foram observadas no parênquima rodeadas por hepatócitos em degeneração, neutrófilos e eosinófilos, e hemorragia. 0 surto ocorreu em uma propriedade localizada em uma área endêmica para a fasciolose, embora a forma aguda da enfermidade não seja frequente em bovinos nesta região. É provável que as vacas tenham se infectado pelas metacercárias liberadas do hospedeiro intermediário no final do outono ou no início da primavera na resteva de arroz onde foram colocadas antes da parição. Embora mortalidade em bovinos devido à fasciolose seja infrequente, surtos podem ocorrer e a utilização de fasciolicidas eficientes para controlar as formas imaturas ou adultas deste parasita devem ser administradas aos bovinos para evitar eventuais perdas econômicas.

TERMOS DE INDEXAÇÃO: Fasciolose, Fasciola hepatica, fasciolose aguda, bovinos.

\section{INTRODUÇÃO}

Fasciolosis is one of the most important parasitic diseases in domestic ruminants throughout the world. The disease is caused by the trematode Fasciola hepatica, which has a cosmopolitan distribution (Radostits et al. 2007). The liver fluke infection occurs in ruminants, resulting in poor productivity, reduced milk yields and condemned livers at slaughter (Van Dijk et al. 2010). It is an economically significant parasite in livestock and is emerging as an important zoonotic infection in humans (Fairweather 2011).

In southern Brazil, the rate of liver condemnation at slaughter due to infection by $F$. hepatica varies from $18.6 \%$ to $19.6 \%$ in cattle and $2.27 \%$ to $14.57 \%$ in sheep (Ueno et al. 1982, Cunha et al. 2007, Dutra et al. 2010). The Patos, Mirim, and Mangueira lakes and a flat topography with wetlands used to irrigated rice fields contribute to the dissemination and maintenance of a high frequency of flukes throughout the year in the southeast region of the Rio Grande do Sul state (Cunha et al. 2007). In Brazil, the following three species of Lymnea have been reported as intermediate hosts for F hepatica: Lymnea columella in Rio de Janeiro, São Paulo, Minas Gerais, Santa Catarina, and Rio Grande do Sul; Lymnea cubensis in Rio de Janeiro; and Lymnea viatrix in Rio Grande do Sul (Echevarria 2004). In the municipality of Santa Vitória do Palmar, the only species that has been reported is L. viatrix (Müller 2007).

Fasciolosis outbreaks with a high mortality rate occur in sheep in this region (Fiss et al. 2012). However, fasciolosis is not lethal in cattle, and bovines rarely acquire the acute form of the parasitosis (Müller 2007). Mortality rates due to acute fasciolosis in sheep have been reported to range from $15 \%$ to $20 \%$ (Echevarria 2004) and 3\% to 50\% (Fiss et al. 2012). The incidence of the disease in bovines has increased worldwide in recent years as a possible consequence of global climate changes (Fairweather 2011).

Fasciolosis can present as subclinical, acute, subacute, or chronic based on the number of metacercariae ingested. The acute and subacute forms of the disease are primarily due to mechanical damage caused by simultaneous migration of immature flukes in the hepatic parenchyma (Müller 2007). Chronic fasciolosis develops when the adult parasites migrate to the bile ducts and cause cholangitis, biliary obstruction, and fibrosis (Radostits et al. 2007).

This study reports the epidemiological and clinical-pathological aspects of an outbreak of acute fasciolosis in cattle in southern Brazil.

\section{MATERIALS AND METHODS}

An outbreak of disease in cattle occurred in a farm located at Latitude $32^{\circ} 58^{\prime} 50^{\prime \prime} \mathrm{S}$ and Longitude $52^{\circ} 55^{\prime} 42^{\prime \prime} \mathrm{W}$ in the municipality of Santa Vitória do Palmar, Southern Brazil, was studied. A three years old herd of heifers calved between October and November 2011 began to lose weight 30-40 days before calving and died. The epidemiological and clinical data were gathered from the owner or from the practicing veterinarian by visits to the farm where the outbreak occurred. One heifer that was recumbent for 12 hour was euthanized and necropsied to macroscopic and histological evaluation. The organs were fixed in $10 \%$ buffered formalin, embedded in paraffin, cut into 4-6 $\mu \mathrm{m}$ sections and stained with hematoxylin and eosin.
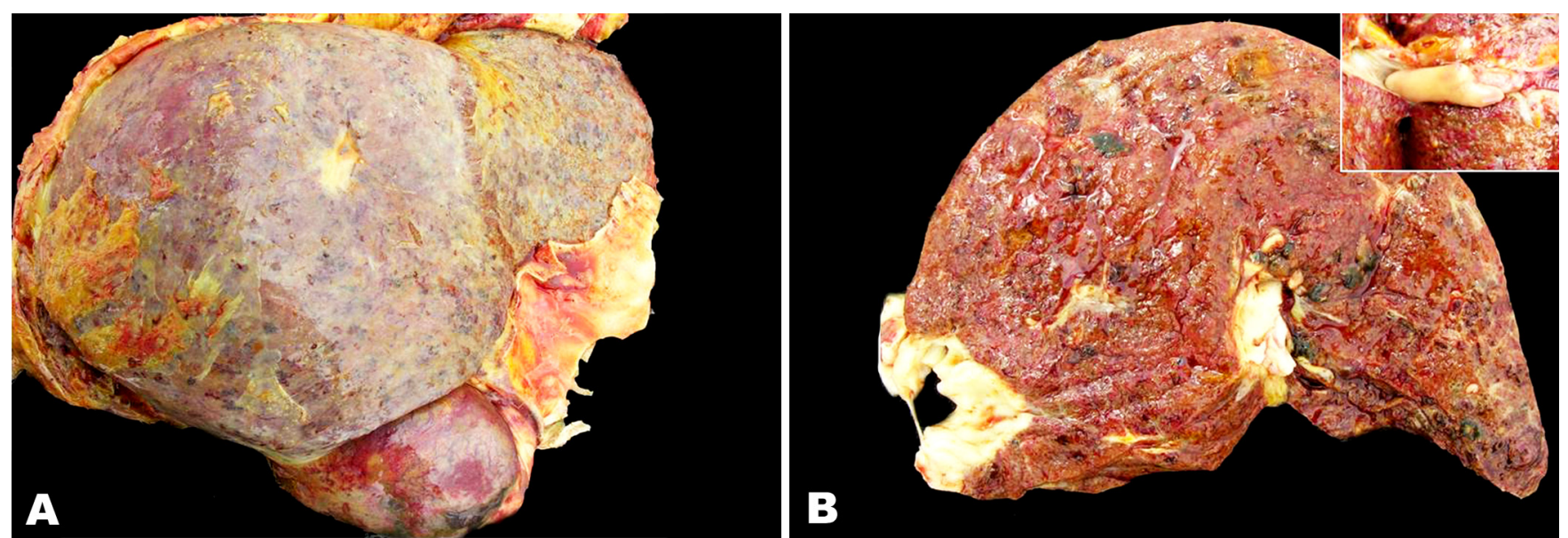

Fig.1. Cattle liver. Acute fasciolosis. (A) The liver is enlarged with rounded edges and an irregular capsular surface with adhered fibrin and red strips interspersed with clear areas and petechiae. (B) The cutting surface is irregular and edematous with hemorrhagic channels, fibrotic areas, dark foci filled with debris, and the presence of different stages of Fasciola hepatica. A fibrin thrombus is observed in a great vessel (Inset). 


\section{RESULTS}

The cows were in a wetland during summer (in February 2011) and returned for calving near the facility in August to a paddock with rice stubble. The cows were treated with Nitroxynil in May and September prior to calving and with Ivermectin after calving. Between October and November 2011,15 of the 70 three-year-old pregnant cows lost weight in the 30-40 days prior to calving. Ten cows aborted and 5 died. Clinical signs included diarrhea, weakness, mild anemia and jaundice.

The necropsied cow showed mild anemia and jaundice. Dark yellow fluid was present in the abdominal cavity, and a thick layer of fibrin caused adhesion among the peritoneum, intestines, diaphragm and liver. The liver was enlarged with rounded edges, and the capsular surface was irregular with adhered fibrin and red strips interspersed with clear areas and petechiae (Fig.1A). At the cut surface, the liver was irregular, firm and edematous with hemorrhagic channels and fibrosis in the hepatic parenchyma (Fig.1B). Ten affected cows that did not die, were sent to slaughter and their livers were condemned by similar fasciolosis lesion. There were several dark foci filled with debris and different stages of $F$. hepatica. There were several whitish

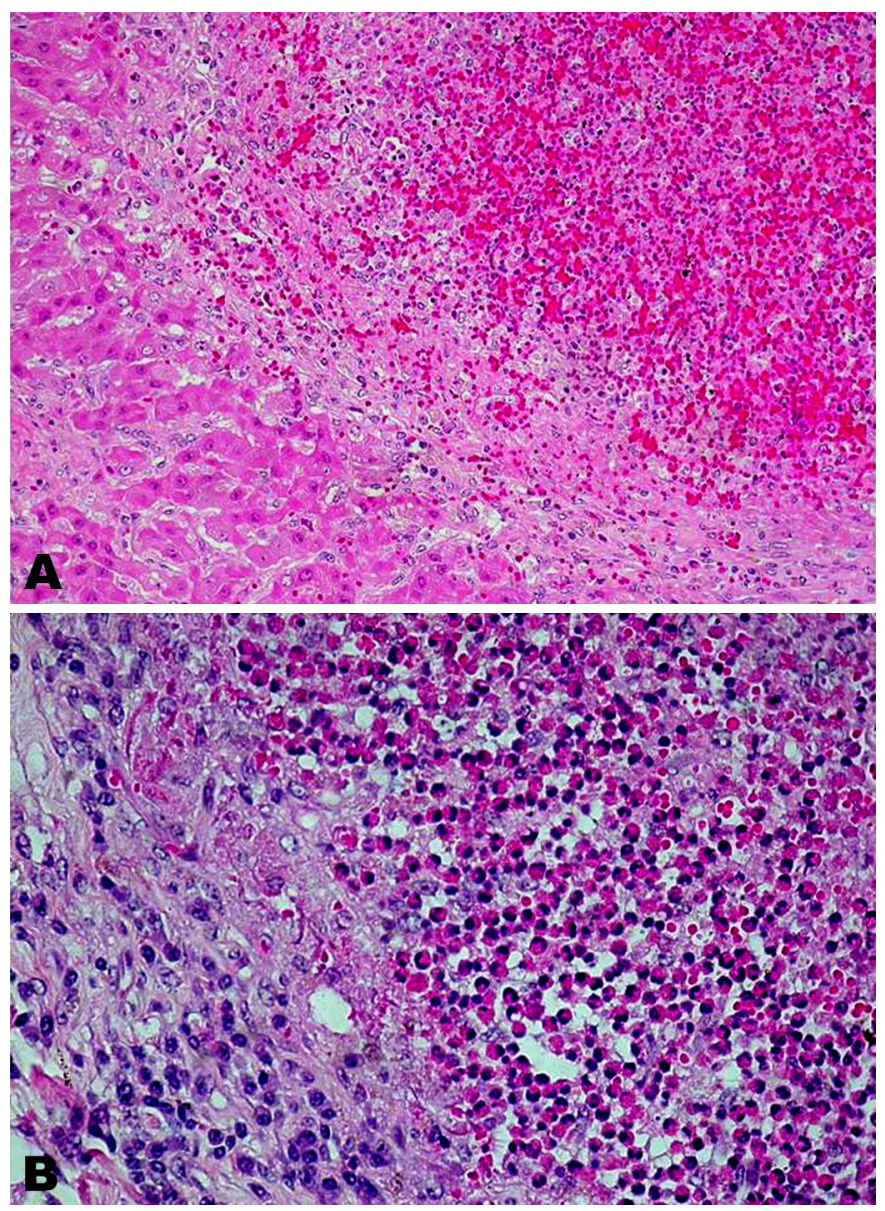

Fig.2. Cattle liver. Acute fasciolosis. (A) A necrotic area with hemorrhages surrounded by degenerating swollen hepatocytes is observed in the liver parenchyma. HE, 200x. (B) Eosinophil infiltration in the liver parenchyma surrounded by fibrous tissue. HE, 400x.
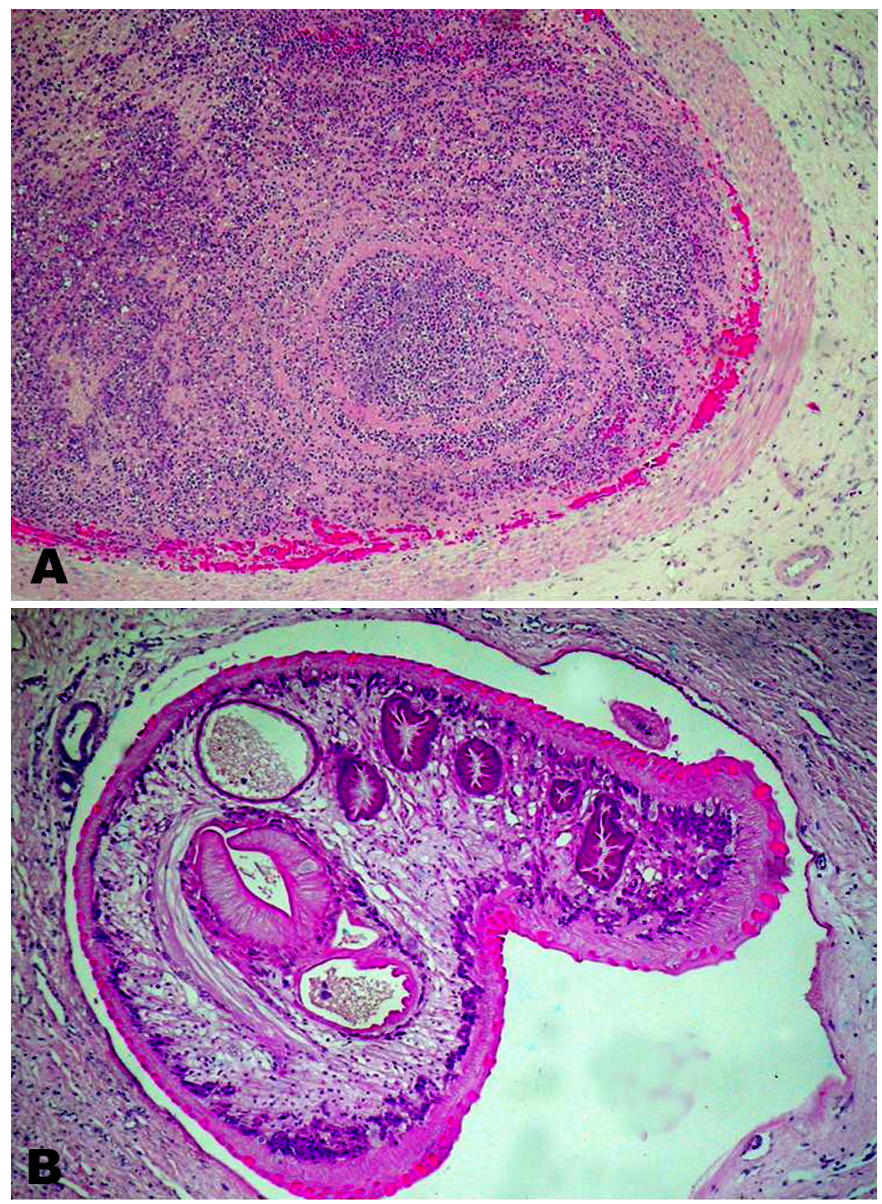

Fig.3. Cattle liver. Acute fasciolosis. A) A vessel occluded by a thrombus is observed. HE, 100x. (B) An immature Fasciola hepatica fluke is surrounded by fibrous tissue. HE, 100x.

thrombi occluding the great vessels (Fig.1B). The gallbladder was enlarged, and its wall was thick and edematous and contained several trematodes. The hepatic lymph nodes were enlarged, and the cut surface was hemorrhagic and edematous. Renal infarction was also observed. Fibrin and clotted blood were adhered to the pericardium and lung, primarily in the diaphragmatic lobes.

Microscopically, the liver showed areas of coagulation necrosis, extensive hemorrhages in streaks or foci (Fig.2A), and disruption of the parenchyma with neutrophil and eosinophil infiltration (Fig.2B). There was also fibrosis and bile duct proliferation in some areas. Several vessels were occluded by thrombi (Fig.3A). Immature F. hepatica flukes were observed in the parenchyma surrounded by fibrosis (Fig. 3B) and degenerated hepatocytes, neutrophils, eosinophils and hemorrhages in several areas. Peritonitis with fibrino-hemorrhagic deposits was observed on the serous surfaces. Multifocal fibrosis, hemorrhages, and neutrophil infiltration were observed in the renal cortex, and hyaline casts were present in the renal tubules.

\section{DISCUSSION}

The diagnosis of acute fasciolosis was made based on macroscopic and histological lesions. Hepatitis with extensive hemorrhages associated with infiltration of neutrophils and eosino- 
phils and the presence of immature Fasciola hepatica flukes in the liver parenchyma are characteristic of the disease.

The outbreak occurred on a farm located in an area endemic for fasciolosis in the southern Rio Grande do Sul state (Marques \& Scroferneker 2003, Müller 2007). However, the acute form of the disease has not been previously reported. It presents a flat topography with wetlands used mainly to cultivate irrigated rice and for sheep and cattle production. The water is pumped from Mirim lake to rice fields through irrigation channels, which are appropriate for the development of the intermediate host. Also the paddocks are frequently flooded favoring the spread and maintenance of the snails throughout the year (Müller et al. 1999). In Brazil this region has the highest percentage of liver condemnation by fasciolosis at slaughterhouses, varying from 18.6\% (Dutra et al. 2010) to 19.6\% (Cunha et al. 2007 ) in cattle, and from $2.27 \%$ to $14.57 \%$ in sheep (Ueno et al. 1982, Cunha et al. 2007).

In this outbreak, it is likely that the cows were infected by metacercariae released in the late fall or early spring in the rice stubble where the herd was grazing prior to calving. The number of cercariae liberated from Lymnaea spp. has been reported to increase considerably in the early spring due to reactivation of the cycle that stopped or was delayed during the winter (Acosta 1994). Ingestion of large numbers of metacercariae in a short period of time may induce acute illness (Radostits et al. 2007). The herd had been treated in May and September with Nitroxynil, but this drug does not act on the immature flukes (Radostits et al. 2007). The treatment of acute fasciolosis must be performed using flukicides that are effective at killing immature $F$. hepatica (Radostits et al. 2007). Because the cattle had remained in the infested area for a long period of time, many infections may have occurred, and the treatment performed in September only eliminated the adult parasites.

Young cattle acquire resistance to fasciolosis when exposed to repeated infestations by the parasite (Acosta 1994). The capsular response appears to stimulate a surface reaction with a consequent fibrous reaction at the capsule itself (Anderson et al. 1978). Clinical fasciolosis can occur in 3 categories of cattle: lactating cows with poor feeding; adult cattle with no previous experience with the parasite; and cattle that have been parasitized infrequently at low levels and are exposed to considerable challenges (Acosta 1994). The latter condition may have occurred in this outbreak. Acute fasciolosis and associated mortalities have been observed in sheep in the same region (Fiss et al. 2012). Acute fasciolosis has been rarely reported in cattle in other countries (Anonymous 2007).

Gross and histologic lesions were typical of acute fluke infection. Peritonitis is due to the migration of immature forms of the parasite in the abdominal cavity. Inflammation involves the parietal peritoneum and the visceral peritoneum, particularly in the liver, spleen, and omentum (Brown et al. 2007). Microscopically, extensive liver damage with hemorrhagic dark red tracts of necrotic liver parenchyma, the presence of immature flukes, and thrombosis of the hepatic vessels during the migratory phase are consistent features of the disease in all species (Dow et al. 1967). Thrombosis occurs over areas of localized phlebitis produced by fluke migration tracks, but in some instances, there is no evidence of damage to the vessel wall in calves (Dow et al. 1967).

Proliferation of fibrous tissue and bile ducts were observed. These chronic lesions were likely induced by previous infections because the farm is located in an area endemic for fasciolosis. In calves, the proliferation of fibroblasts and bile ducts has been observed between seven and eight weeks after a single experimental infection with 200-300 metacercariae (Ross et al. 1966, Dow et al. 1967).

Bovine fasciolosis is generally considered a subclinical disease with economic losses primarily resulting from decreased animal productivity. However, control of $F$. hepatica is complicated by the lack of available drugs with efficacy against parasites younger than 8 weeks and the complexity of the parasite's life cycle and epidemiology. Removal of flukes from infected animals provides an added health benefit, but preventing pasture contamination of infective stages and the subsequent transmission to cattle is the basis of most treatment recommendations (Kaplan 2001).

In conclusion, although mortality due to fasciolosis in cattle is infrequent, outbreaks can occur, and treatments that are efficient in both immature and adult forms of the parasite should be administered to prevent economic losses that go beyond condemnation of the liver at the slaughterhouse.

\section{REFERENCES}

Acosta D. 1994. Epidemiologia y control de Fasciola hepatica en el Uruguay, p.233-256. In: Nari A. \& Fiel C. (Eds), Enfermidades Parasitárias de Importancia Economica en Bovinos. Editorial Hemisferio Sur, Montevideo.

Anderson P.H., Berrett S. \& Patterson D.S.P. 1978. Resistence to Fasciola hepatica in cattle. II. Biochemical and morphological observations. J. Comp. Pathol. 88:245-251.

Anonymous 2007. Acute fasciolosis diagnosed in young Scottish calves. SAC Veterinary Services-Surveillance Report. Vet. Rec. 161: 249-252.

Brown C.C., Baker D.C. \& Barker I.K. 2007. Alimentary system, p.279-296. In: Maxie M.G. (Ed.), Jubb K.V.F., Kennedy P.C., Palmer N.C., Pathology of Domestic Animals. Vol.2. Elsevier Saunders, London.

Cunha F.O.V., Marques S.M.T. \& Mattos M.J.T. 2007. Prevalência de Fasciola hepatica em ovinos no Rio Grande do Sul, Brasil. Parasitol. Latinoam. 62:188-191.

Dow C., Ross J.G. \& Todd J.R. 1967. The pathology of experimental fasciolosis in calves. J. Comp. Pathol. 77:377-385.

Dutra L.H., Molento M.B., Naumann C.R.C., Biondo A.W., Fortes F.S., Savio D. \& Malone J.B. 2010. Mapping risk of fasciolosis in the south of Brazil using geographic information system. Vet. Parasitol. 169:76-81.

Echevarria F. 2004. Fasciolose. Revta Bras. Parasitol. Vet. 13:100-102.

Fairweather I. 2011. Reducing the future threat from (liver) fluke: realistic prospect or quixotic fantasy? Vet. Parasitol. 180:133-143.

Fiss L., Adrien M.L., Marcolongo-Pereira C., Assis-Brasil N.D., Ruas J.L., Sallis E.S.V., Riet-Correa F. \& Schild A.L. 2012. Subacute and acute fasciolosis in sheep in Southern Brasil. Parasitol. Res. DOI 10.1007/s00436012-3096-2.

Kaplan R.M. 2001. Fasciola hepatica: a review of the economic impact in cattle and considerations for control. Vet. Therap. 2:40-50.

Marques S.M. \& Scroferneker M.L. 2003. Fasciola hepatica infection in cattle and buffaloes in the state of Rio Grande do Sul, Brazil. Parasitol. Latinonam. 58:169-172.

Müller G., Berne M.E.A., Raffi L.L., Jesus L.P., Paulsen R.M.M. \& Sinkoc A.L. 1999. Influência da temperatura na longevidade de metacercárias de Fasciola hepatica. Revta Bras. Agrociência 2:164-165. 
Müller G. 2007. Fasciolose, p.639-650 In: Riet-Correa F., Schild A.L., Lemos R.A.A. \& Borges J.R.J. (Eds), Doenças de Ruminantes e Equídeos. Vol.1. 3 a ed. Pallotti, Santa Maria.

Radostits O.M., Gay C.C., Hinchcliff K.W. \& Constable P.D. 2007. Veterinary Medicine: a textbook of the diseases of cattle, horses, sheep, pigs and goats. $10^{\text {th }}$ ed. W.B. Saunders, Edinburgh. 2156p.

Rahko T. 1969. The pathology of natural Fasciola hepatica infection in cattle. Pathol. Vet. 6:244-256.
Ross J.G., Todd J.R. \& Dow C. 1966. Single experimental infections of calves with the liver fluke, Fasciola hepatica (Linnaeus, 1758). J. Comp. Pathol. 76:67-81.

Ueno H., Gutierres V.C., Mattos M.J.T. \& Müller G. 1982. Fascioliasis problems in ruminants in Rio Grande do Sul, Bazil. Vet. Parasitol. 11:185-191.

Van Dijk J., Sargison N.D., Kenyon F. \& Skuce P.J. 2010. Climate change and infectious disease: helminthological challenges to farmed ruminants in temperate regions. Anim. 4:377-392. 